\title{
MULTICRITERIAL EVALUATION IN THE DEFINITION OF PROTECTED AREAS AT THE PIEDADE MUNICIPALITY, SP.
}

\author{
Simone Sayuri Sumida ${ }^{2 *}$ and Roberta Averna Valente ${ }^{3}$
}

${ }^{1}$ Received on 10.07.2018 accepted for publication on 21.08.2019.
2Instituto de Botânica de São Paulo, São Paulo, SP - Brasil. E-mail: <sasumi.si@gmail.com>.
${ }^{3}$ Universidade Federal de São Carlos, Departamento de Ciências Ambientais, São Paulo, SP - Brasil. E-mail: <roavalen@ufscar.br>.
${ }^{*}$ Corresponding author.

ABSTRACT - The preservation in situ, through the establishment of legally protected areas, is one the approaches to mitigate environmental impact and protect biodiversity in the long term. The Piedade municipality shows a favorable set of conditions for consolidating protected areas (i.e. relatively low urbanization rates, the presence of forest remnants, and portions of relevant conservation units). In this context, the present study proposed the definition of priority areas for protection using Multicriteria Evaluation (MCE). The specific objectives were to identify the criteria and weights that are important for defining protected areas and to evaluate which method of MCE, whether the Weighted Linear Combination (WLC) or the Ordered Weighted Averaging (OWA) would be more appropriate. Using the Participatory Technique (PT), we defined criteria and weights. WLC and OWA made possible the identification of areas likely to become protected, but the first method produced more general and less flexible solutions. On the other hand, OWA provided a greater number of possible answers to the question of interest. Thus, showing the low-risk level, the OWA map was considered most suitable for the study proposal.

Keywords:Weighted Linear Combination; Ordered Weighted Averaging; Landscape Ecology.

\section{AVALIAÇÃOMULTICRITERIALNADEFINIÇÃODEAREASPROTEGIDAS, NO MUNICÍPIO DE PIEDADE-SP}

RESUMO - Uma das abordagens utilizadas para mitigar impactos e proteger a diversidade biológica, em longo prazo, é a preservação in situ, por meio do estabelecimento de áreas legalmente protegidas. O município de Piedade apresenta um conjunto de condições favoráveis à consolidação de áreas protegidas (urbanização relativamente baixa, presença de remanescentes florestais e relevantes Unidades de Conservação com porções dentro de seus limites). Nesse contexto, o presente trabalho teve por objetivo geral definir áreas prioritárias à proteção, por meio da Avaliação Multicriterial (AMC). Os objetivos especificos foram identificar os fatores $e$ pesos importantes à definição das mesmas e avaliar qual método de AMC, se a Combinação Linear Ponderada (CLP) ou se a Média Ponderada Ordenada (MPO) seria mais apropriada para o presente estudo. Os critérios e seus respectivos pesos foram definidos por meio da Técnica Participatória. Tanto a CLP quanto a MPO possibilitam a identificação de áreas propensas a se tornarem protegidas, porém a CLP produziu soluções mais gerais e menos flexíveis. A MPO forneceu uma maior quantidade de possíveis respostas à questão de interesse. O mapa obtido por meio da MPO, com risco baixo de tomada de decisão, foi consi-derado o mais adequado para a proposta do estudo.

Palavras chave: Combinação Linear Ponderada; Média Ponderada Ordenada; Ecologia da Paisagem. 


\section{INTRODUCTION}

Currently, biodiversity is under threat due to human consumption needs and expansion. So, the preservation in situ, through the establishment of legally protected areas, has been one approach proposed to mitigate environmental impact and protect biodiversity long term.

In this context we have the Piedade municipality, showing a favorable conditions for establishing protected areas, such as relatively low urbanization rates; presence of forest remnants, that occupy approximately $25 \%$ of the municipality; and portions of relevant Conservation Units (CU), that are named Itupararanga Environmental Protection Area (EPA), in the northeast region, and the Jurupara State Park (PEJU), in the southeast region.

Multicriteria Evaluation (MCE) is a technique that can support the protected areas definition. It allows the transformation and combination of different criteria, considering its relevance, and influence level, in order to provide solutions/alternatives for the decision-making process.

The Weighted Linear Combination (WLC) and Ordered Weighted Averaging (OWA) are among the MCE methods. The first involves a criteria normalization to a common scale, the definition of criteria weights (i.e. factors weights), and their aggregation using a weighted average (Voogd, 1983). Such methodology provides medium risk solutions, and it is considered an OWA variation (Malczewski; Rinner, 2015).

Differently, OWA not considers only the factor weights, having also a second group of weights called order weights (Yager, 1988), that control the trade-off levels among the criteria and the decision process risk-taking (Valente; Vettorazzi, 2008).

Using OWA, the solution can be located between the extremes (risk-taking and risk-averse), considering that this position (or factor order) will influence the risk level (Malczewski, 2004).

WLC has been used for many purposes as the environmental quality analyzes and valuation of ecosystem services (Comino, et al., 2014), selection of possible locations for solar power plants (Zoghi et al., 2015; Doorga; Rughooputh; Boojhawon, 2019), for biomass plants (Jeong; Ramírez-Gómez, 2017) and for anaerobic digestion facilities for food and biodegradable waste (Babalola, 2018); also studies on ecological-urban vulnerability (Zhang; Wang; Lin, 2015), evaluation of accessibility to lignite deposits (Blachowski, 2015), definition of priority areas for forest restoration in urban environments (Valente et al., 2017), mapping of landslide susceptible areas (Lorentz et al., 2016), monitoring of natural areas considered World Heritage Sites by UNESCO (Wang; Du, 2016), indication of suitable locations for electrical vehicle charging stations (Costa et al., 2018) and disposal of hazardous waste (Danesh et al., 2019).

Similarly, OWA has been employed to identify relevant areas for forest restoration, aiming at sustainable water management (Valente; Vettorazzi, 2013); also in determining potential ecological corridors and stepping stones (Ferretti; Pomarico, 2013), as support for ecological planning (Comino et al., 2016), when evaluating flooding risks (Xiao; Yi; Tang, 2017), in geothermal prospecting (Kiavarz et al.,2017), in soil fertility analyzes (Mokarram; Hojati, 2017), when indicating suitable locations for citrus cultivation (Zabihi et al., 2019) and primordial areas for preserving multiple ecosystem services (Zhang et al., 2015), when choosing locations for photovoltaic power plants (Suuronen et al., 2017) and recommending potential locations for mining tailings disposal sites (Aires et al., 2018).

In this context, this study aimed at the identifying of priority areas for biodiversity protection at the Piedade municipality, using Multicriteria Evaluation Methods (MCE). The specific objectives were the criteria definition, considering their weights for the prioritization of areas; and the WLC and OWA methods evaluation for the definition of biodiversity protection areas.

\section{MATERIAL AND METHODS}

\subsection{Study area}

The Piedade municipality is located at the southeast portion of the São Paulo state, between coordinates UTM 253551-257159 W and 7385600$7345310 \mathrm{~S}$, having an area of approximately $747 \mathrm{~km}^{2}$ and population around 55.092 habitants (IBGE, 2017).

In the northeast portion of the Piedade is the Itupararanga EPA and in the southeastern portion is

Revista Árvore 2019;43(3):e430307 
the PEJU, highlighting its considerable richness of flora and fauna species (Figure 1).

The PEJU management plan mentions that the buffer zone is composed by portions of the municipalities (i.e. Piedade, Ibiúna, Juquitiba, Miracatu, Juquiá, and Tapiraí) and, also by parts of the Serra do Mar EPA and the Itupararanga EPA, resulting in a mosaic with different landscapes (Fundação Florestal, 2010).

The municipality shows altitude of approximately $800 \mathrm{~m}$ and tropical altitude climate (Cwa - Köppen classification) with mean annual temperatures varying from $13.5^{\circ} \mathrm{C}$ to $25.7^{\circ} \mathrm{C}$ and $1354.7 \mathrm{~mm}$ of rain (Cepagri, 2013). Located at the crystalline Atlantic Plateau, the municipality characterizes by sharp mountainous relief (Prefeitura de Piedade, 2012).

The municipality is occupied by pastures (43.61\%), native forests $(40.40 \%)$, exposed soil $(4.93 \%)$, planted forests $(4.14 \%)$, roads $(4.45 \%)$, urban areas $(0.95 \%)$, agriculture $(0.81 \%)$, and drainage network (0.66\%) (Gasparoto et al.,2011).

\subsection{Multicriteria Evaluation (MCE)}

\subsubsection{Criteria}

The criteria were defined through the literature review and Participatory Technique (PT), considering the opinion of nine experts, representing areas as geoprocessing, nature conservation, and landscape

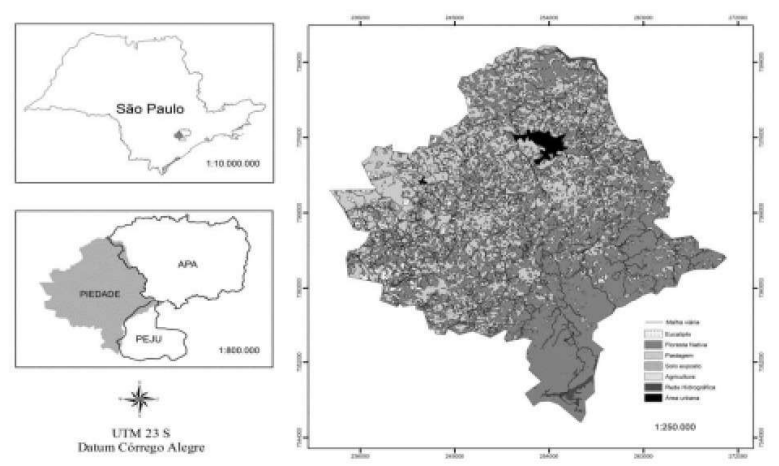

Figure 1 - Land-use/land-cover and location of the Piedade municipality, Jurupara State Park (PEJU), and the Itupararanga Environmental Protection Area (Itupararanga EPA), the Sao Paulo state (SP), Brazil.

Figura 1 - Uso e cobertura do solo e localização do município de Piedade, do Parque Estadual do Jurupará (PEJU) e da Area de Proteção Ambiental de Itupararanga (APA de Itupararanga), no Estado de São Paulo (SP), Brasil. ecology. Considering grades from 0 to 10 , experts associated weights to criteria, took into account their importance to define protection areas. We selected the criteria set most mention in the TP, which were: proximity among forest patches with larger core, neighbor of forest remnants, distance from disturbance sources, and proximity to protected areas (i.e. PEJU and Itupararanga EPA). The experts mentioned other criteria, but, some of them did not in accordance to the study objective or, they were indirectly included in selected criteria.

We produced the maps in a GIS environment (Idrisi Selva and ArcGis 10.0), a standardizing the cartographic database to Corrego Alegre Datum and UTM $23 \mathrm{~S}$ coordinate system, following a pre-existing database.

\subsubsection{Proximity among forest patches with larger core}

Core areas correspond to an internal area of space elements and in the case of the forest remnants, the edge-equivalent part is excluded. Peripheral areas, due to edge effect, especially in the first $35 \mathrm{~m}$ (Rodrigues, 1998), are generally avoided by sensitive animals to potential disturbances. Small patches or patches with great edge effect present core areas that tend to zero (Lang; Blaschke, 2009). Edge effects contribute to increasing rainforest destruction (Primack; Rodrigues, 2001).

Large and interconnected patches have a trend to shelter a greater number of species and populations less vulnerable to extinction than smaller isolated patches (Geneletti, 2005). A single patch can possess considerable width to hold some species but may not have enough core area to support a viable population (Turner; Gardner, 1990). According to Valente and Vettorazzi (2008), proximity among forest patches with larger core was considered the most important factor when defining priority areas for forest conservation. Therefore, for the present study, the regions with the largest core patches were considered more relevant.

The proximity among forest patches with larger core map (Figure 2A) was produced by Gasparoto et al. (2011), considering the layer core area (i.e. core areas of the forest patches).

Firstly, the core areas (in hectares - ha) were classified into five size classes (smaller than 50 ha, 
50 to 100 ha, 100 ha to 150 ha, 150 ha to 200 ha, and larger/equal to $200 \mathrm{ha}$ ). After we attributed weights (values from 1 to 5) for the classes, according to their size (i.e. lower weights were attributed to smaller forest patches).

After this first step, distances between the five classes were calculated, core areas were recombined and standardized on a scale from 0 to 255 bytes. Values close to 255 bytes corresponded to patches with large cores areas close to other patches also with large cores areas and were considered the most important regions.

Proximity among forest patches with larger core map is important because when isolation among forest patches with large cores areas decreases, the chances of reestablishing landscape structural connectivity rise, allowing future functional connection and genetic flow between populations.

\subsubsection{Proximity to protected areas}

Areas close to protected areas can promote landscape connectivity, ensuring the long-term viability of flora and fauna (Ribeiro et al., 2012). An ideal scenario would be one with large forest remnants, few recesses and an approximately circular shape (Matsumoto; Kumler; Baumgarten, 2012).

Fragment size has a strong effect on edge and inland species but is irrelevant to generalist species (Bender; Contreras; Fahrig, 1998). Because of this, large and close fragments were prioritized in a connectivity study and planning of possible Integral Protection Conservation Units (Metzger et al., 2008). Krishnadas et al. (2018) found that protected areas, when away from highways, reduced forest loss (reducing deforestation by $88 \%$ ) in a global biodiversity hotspot in India.

Considering the limits layer of the protected areas and a distance algorithm in the GIS, we obtained the distance maps to protected areas (i.e. Itupararanga EPA and PEJU), that were normalized to the common scale (i.e. 0 to 255 bytes), through a decreasing linear function (Figures $2 \mathrm{C}$ and $\mathrm{D}$ ). Thus, regions near to the limits of the protected areas are more appropriate to be a protected area.

\subsubsection{Distance from disturbance sources}

The implementation and expansion of urban areas often perform interconnected environmental impacts such as deforestation, disturbances in the hydrological cycle, imperviousness of soil (thereby reducing the recharge of aquifers) and increased runoff, favoring problems such as floods, and several types of pollution generated by anthropic occupation, which lead to the spread of diseases, among other consequences (Castro, 2007).

According to Kamwi et al. (2018), an enhance in the distance of protected areas from settlements reduces the likelihood of conversion from forest to bare soil or crops and pastures. Neighboring urban centers, even when showing low population density, exert strong pressure on forest remnants (Zimbres; Machado; Peres, 2018). In a study conducted by Rodríguez-Rodríguez and Martínez-Vega (2019), the distance from cities was the variable that most influenced on the isolation of protected areas. Palomino and Carrascal (2007) observed biotic uniformization in birds due to the proximity to an urban area and thereby, urban explorer birds were the only ones that had a positive association with roads. They noted that most of the disturbances associated with urban areas do not differ much from those related to highways.

Road construction is considered one of the causes of fragmentation (Schonewald-Cox;Buechner,1992) that involves two distinct processes, the breaking apart of habitat and, habitat loss (Farihg,2003). The last one is considered the biggest threat to biodiversity worldwide (Tabarelli; Gascon, 2005). Moreover, Maués and De Oliveira (2010) mention that fragmentation can reduce gene flow rates and tree recruitment and fructification, and increase the possibility of inbreeding, also affecting pollinator populations which can have narrow coevolutionary relationships to tree species.

Roads drive changes in land use and influence deforestation (Freitas et al., 2010). Another relevant aspect is that marginal areas of highways present a high risk of forest fires due to car accidents and bonfires produced by passers-by (Silveira et al., 2008). De Jesus Silva et al. (2006) reported the importance of considering the effects of road network density on biodiversity when implanting a CU because highways can disrupt the interaction between seeds dispersal by rodents and plants, impacting in regeneration and composition of forests (Chen et al. al., 2019). Besides, they make it possible to raise the invasion of exotic plant species into the landscape and facilitate

Revista Árvore 2019;43(3):e430307 
future occupations (Parendes; Jones, 2000), leading to a homogenization of species richness and plant community patterns in mountainous regions (Haider et al., 2018; Medvecka et al., 2018). Sousa et al. (2009) also highlighted the need for considering road distance as a determining factor in the distribution of native vegetation and $\mathrm{CU}$.

Another factor to be considered is that these structures enlarge the effective distance, i.e., the "cost" to cross them increases (Metzger, 2006). Some animals tend to avoid roads (Mcgregor et al., 2008), such as gazelles that prefer to move away from habitats with high noise pollution, causing loss of functionality of these sites (Ghadirian et al., 2019). Road lights can disorient birds and noise can affect their reproductive behavior (Glista; Devault; Dewoody, 2009). The opposite effect may also occur, since the presence of carcasses of roadkill may induce the approach of carnivores and other animals, such as skunks that are attracted by the accumulation of garbage, increasing the risk of new accidents (Bueno; and Almeida, 2010).

In this context, we considered the urban areas and the roads as disturbance sources. These features were extracted by the land-use/land-cover map (Figure 1), composing the disturbance sources map. Firstly, we calculated the distance from the disturbance sources and, after, the distance as from them. The distance map was normalized ( 0 to 255 bytes scale) using a decreasing linear function, which high priority areas (close to 255 bytes) corresponded to regions more distant from urban areas and roads.

\subsubsection{Neighbor of forest remnants}

Viana and Pinheiro (1998) found that strategies for biodiversity conservation in CU must extrapolate their boundaries and consider the characteristics and conservation potential of neighboring fragments, based on a study carried out in a forest patch surrounded by both pastures and Pinus sp. plots, in which pastures exerted higher edge effects than plots. Therefore, depending on the neighborhood, more intense edge effects may or may not occur in forest patches.

Mazarolle and Villard (1999) noticed that local habitat conditions are not always adequate for explaining species abundance and boundaries and that neighboring characteristics (landscape context) should also be considered. Hence, both the surrounding matrix and core areas must be considered in landscape planning to ensure the persistence, resilience of ecosystem functions, biodiversity and ecosystem services (Svensson et al., 2019).

Thus, different weights were attributed to landuse/land-cover classes in the map of neighboring forest remnants (Figure 2E). The most important classes received higher weights, with the soil exposed receiving the same weight of the agriculture. On the other hand, we did not consider the drainage network. This first map was overlapped with the distance to forest patches map.

So, considering the forest patches (also extracted from land-use/land-cover map), we calculated the distances among patches, that was normalized to the common scale, by a decreasing linear function. After, the two maps were overlapped and, the product was normalized again resulting in the neighbor of forest remnants criterion map.

\subsubsection{Factor weights (Fw)}

Factor weights indicated by the PT were readjusted according to a continuous scale of values and evaluated under the Analytical Hierarchical Process (AHP) (Saaty, 1977) using a Pairwise Comparison matrix.

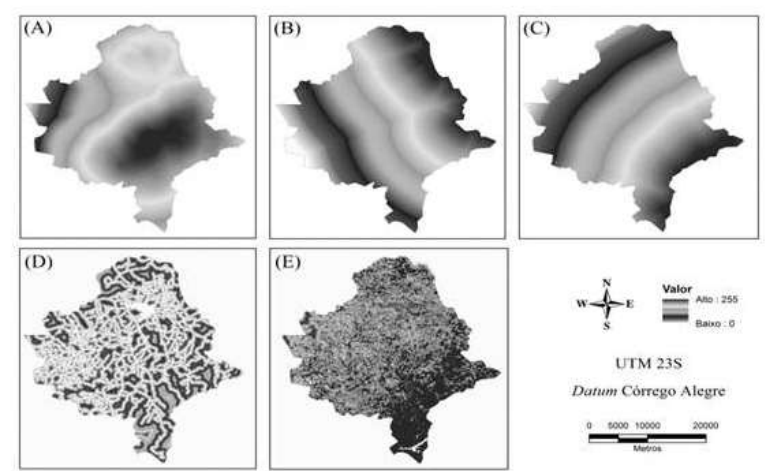

Figure 2 - Criteria maps to the Piedade municipality (SP, Brazil): (A) proximity among forest patches with larger core, (B) proximity to the Itupararanga Environmental Protection Area (Itupararanga EPA), (C) proximity to the Jurupara State Park (PEJU), (D) distance from disturbance sources and (E) neighbor of forest remnants.

Figura 2 - Mapas de fatores para o município de Piedade (SP, Brasil): (A) Proximidade entre fragmentos florestais com maior área nuclear, (B) Proximidade à Área de Proteção Ambiental de Itupararanga (APA de Itupararanga), (C) Proximidade ao Parque Estadual do Jurupará (PEJU), (D) Distância às fontes de distúrbio e (E) Vizinhança aos remanescentes florestais. 
Consistency Rates (CR) were generated and the smallest value (0.06) different from 0.00 was chosen. Factor weights obtained using the matrix were 0.3697 for proximity among forest patches with larger core; 0.2028 for distance from disturbance sources; 0.1571 for both proximity to PEJU and proximity to the Itupararanga EPA; and 0.1133 for neighbor of forest remnants.

\subsection{Criteria aggregation by Weighted Linear Combination (WLC)}

The criteria were combined using a weighted average (i.e. WLC algorithm), producing a final map of priority areas for biodiversity protection. After, evaluation the map histogram, we defined the class range.

According to Jiang and Eastman (2000), WLC assumes $100 \%$ trade-off among criteria, considering that the factor weights cannot control the trade-off, because they only reflect their importance into the decision-making process.

\subsection{Criteria aggregation by Ordered Weighted Averaging (OWA)}

OWA requires the definition of the order weights and trade-off level among criteria, which were defined according to Valente and Vettorazzi (2008). So, we obtained seven priority maps, using OWA to the criteria aggregation and we selected only two maps.

These maps showed 56\% trade-off among criteria, having the first medium-high risk-taking $(\mathrm{R}=$ $0.4650)$ and the second low risk-taking $(\mathrm{R}=0.7187)$.

The same way, the histograms of the maps were evaluated, and these maps were reclassified into priority classes, that support the comparison among their and the WLC map.

\section{RESULTS}

\subsection{Weighted Linear Combination}

According to the WLC priority map, southeast of Piedade was predominantly classified as a high priority for protection. Furthermore, "longitudinal strips" are formed to the west of the municipality, that was associated with very high, medium, low and very low priorities. The latter priority class occupies a restrict area in the western extremity of the municipality, representing only $0.10 \%$ of the total area. Low to very low priority classes respectively represent $5.31 \%$, $19.78 \%, 47.76 \%$ and $27.02 \%$ of the total area.

\subsection{Ordered Weighted Averaging}

\subsubsection{Medium-high risk-taking}

The map produced by OWA, having mediumhigh risk-taking $(\mathrm{R}=0.4650)$ and $56 \%$ trade-off among criteria, presented the priority classes high and very high occupying similar areas of the Piedade (Figure 4).

The first class occupied $38.16 \%$ of the municipality and the second, $39.36 \%$, representing approximately $78 \%$ of Piedade. Therefore, the classes very low, low, and medium occupied respectively $0.07 \%, 3.88 \%$, and $18.50 \%$.

\subsubsection{Low risk-taking}

The map produced by OWA, having low risktaking $(\mathrm{R}=0.7187)$ and $56 \%$ trade-off among criteria, presented differences in relation to the first OWA. According to this map, $56 \%$ of the Piedade was classified as medium priority to protected (Figure 5).

In this scenario, the priority classes very high occupied $5.86 \%$ of the municipality and high $26.01 \%$ and, both were concentrated further southeast of the municipality. Thus, the class very low represented only $0.75 \%$ of the study area, concentrating far west of the municipality.

\section{DISCUSSION}

\subsection{Weighted Linear Combination}

In the WLC map, the spatial distribution of priority classes reflects the importance of the criteria,

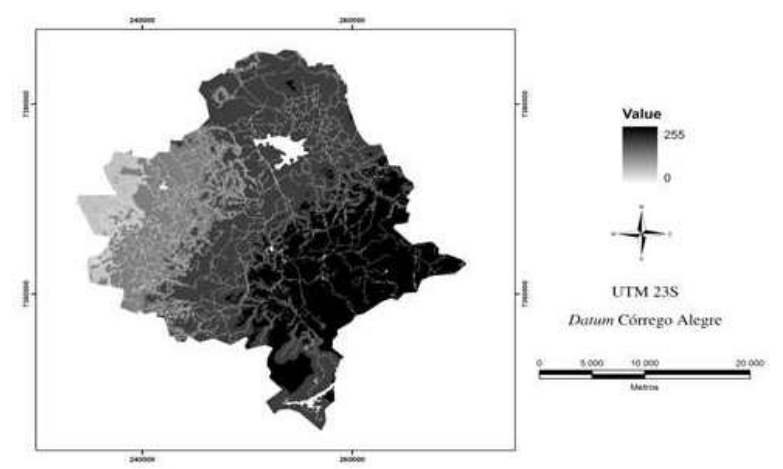

Figure 3 - Priority areas for biodiversity protection to the Piedade municipality (SP, Brazil), obtained by Weighted Linear Combination (WLC) method.

Figura 3 - Áreas prioritárias à proteção da biodiversidade para o município de Piedade (SP, Brasil), obtidas por meio da Combinação Linear Ponderada (CLP). 


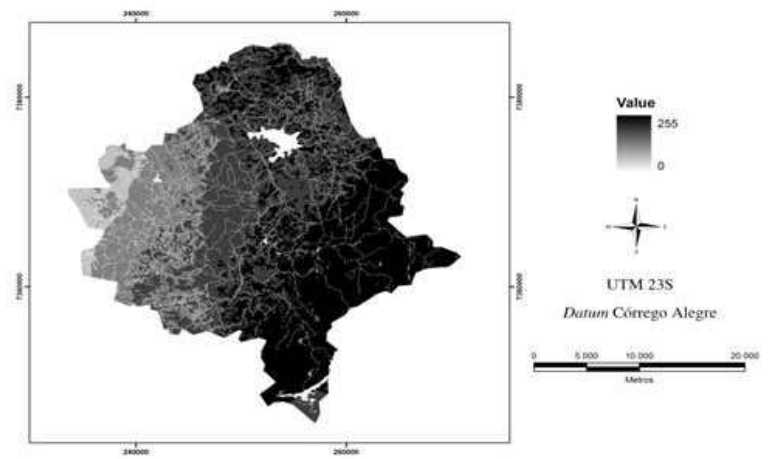

Figure 4 - Priority areas for biodiversity protection to the Piedade municipality (SP, Brazil), obtained by Ordered Weighted Averaging (OWA), with high-medium risk-taking $(\mathrm{R}=$ 0.4650 ) and $56 \%$ trade-off.

Figura 4-Áreas prioritárias à proteção da biodiversidade para o municipio de Piedade (SP, Brasil), obtidas por meio da Média Ponderada Ordenada (MPO), com risco médioalto $(R=0,4650)$ e compensação de $56 \%$.

that were the most influential in the decisionmaking process (i.e. proximity to protected areas and Proximity among forest patches with larger core maps). Consequently, this map shows the priority classes very high and high totalizing $75 \%$ of the municipality.

The least influential criteria (i.e. distance from disturbance sources and neighbor of forest remnants) were practically disregarded in the final product, even though the first showed $20 \%$ importance (factor weight). However, as mentioned by Geneletti

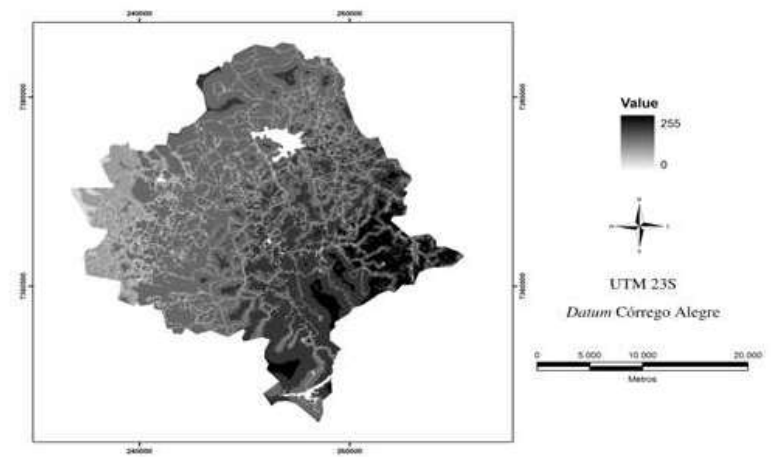

Figure 5 - Priority areas for biodiversity protection to the Piedade municipality (SP, Brazil), obtained by Ordered Weighted Averaging (OWA), with low risk-taking $(\mathrm{R}=0.7187)$ and $56 \%$ trade-off.

Figura 5 - Áreas prioritárias à proteção da biodiversidade para o município de Piedade (SP, Brasil), obtidas por meio da Média Ponderada Ordenada (MPO), com risco baixo $(R$ $=0,7187)$ e compensação de $56 \%$.
(2003), the presence of roads cannot be disregarded in a landscape, seeing that they are responsible for modifying habitat conditions and may affect the abundance and distribution pattern of the biota.

According to Chen et al. (2019), 90.7\% of protected areas are disturbed by the presence of roads. De Jesus Silva et al. (2006) and Sousa et al. (2009) also stress the importance of considering roads when establishing a Conservation Unit. In this context, the WLC map was not adequate for selecting priority areas for protection in the municipality of Piedade.

As reported by Valente and Vettorazzi (2008), WLC maps are equivalent to those showing medium risk-taking and total trade-off between criteria obtained by OWA. Valente and Vettorazzi (2013) stated that WLC products are strongly influenced by their highest-ranking criteria, with one or two priority classes often occupying large regions of the study area.

\subsection{Ordered Weighted Averaging}

\subsubsection{Medium-high risk-taking}

Spatial distribution of priority classes in the medium to high risk-taking map is related to order weights. The lowest values of order weights associated with distance from disturbance sources and neighbor of forest remnants (both with order weights of 0.0080), which are the least influential criteria in the decision-making process. In this case, the tradeoff was low, and criteria continued to show reduced influence just as was seen using WLC.

Consequently, area percentage decreased in very low and low priority classes in comparison to WLC. Conversely, the highest order weight associated with proximity among forest patches with larger core $(0.50)$ and proximity to PEJU (0.30), which already showed high influence, once forest continuity interconnects with core conservation, which in turn is considered a natural refuge (Svensson et al., 2019).

Proximity to the Itupararanga EPA, a very influential criteria, received the second lowest ranking weight (0.04), showing high trade-off between weights and causing a reduction of the factor's influence. Such fact did not significantly alter the final map configuration due to order weights associated to the other two proximity maps.

Revista Árvore 2019;43(3):e430307 
The medium to high risk-taking map allowed prioritization in order to preserve forest patches that already showed established internal structure. According to Geneletti (2005), large interconnected patches tend to harbor more species and less vulnerable to extinction populations compared to smaller, isolated patches. However, as has occurred previously, the medium to high risk-taking map did not considered neighbor of forest remnants and disturbance sources and, thus, could not be considered adequate for selecting priority areas for protection in the municipality of Piedade.

\subsubsection{Low risk-taking}

Spatial distribution of low risk-taking maps portrays the interaction of order weights with factor weights. The lowest order weights associated with the most influential factors, in accordance with the study objectives and following the importance order.

For such purposes, very high and high priority classes locate in the southeast region of Piedade, that is, next to vegetation remnants and Conservation Units, as is shown in factor maps (Figure 5). In those regions, predominant neighboring types are consequently from the native forest category. Ribeiro et al. (2012) mention that locations next to Conservation Units and areas located between forest remnants of significant size and that harbor endemic and/or endangered species can promote landscape connectivity, ensuring long-term viability of flora and fauna.

The lowest concentration of disturbance sources (roads and urban centers) is observed in very high and high priority regions. Priority levels for such portions of the municipality became medium and, when disturbance sources enhance in concentration, especially roads, or when the region distanced from forested areas (remnants or conservation areas), priority levels fell from medium to low or very low. Highways drive change in land use, influence deforestation (Freitas et al., 2010; Bax et al. , 2016), biodiversity loss and raise extinction risk for some species (Ceia-Hasse et al., 2018).

In this context, low risk-taking maps show to be the best solution for selecting priority areas for protection among the three evaluated types and such solution is in accordance with the reality of the municipality. The area between PEJU and the
Itupararanga EPA, associated to very high to medium priority levels, belongs to the PEJU buffer zone and therefore already classifies as a protected area by law.

Such a level of priority reaffirms the need to effectively transform the area into a protected one. The final map, along with criteria maps, demonstrates this region has a potential to increase matrix permeability due to proximity between significant remnants and protected areas. Such an endeavor would be possible by implementing one or more green corridors (Hamad; Kolo; Balzter, 2018) or ecological stepping stones (for example, using backyard agroforestry) (Cambui et al., 2017), which would provide structural connectivity (Metzger, 2006; Guzmán et al., 2016) for remnants, with future expectations of functional connection (Hernández et al., 2015).

\section{CONCLUSIONS}

Considering the specific conditions related to the study, we can conclude that:

1)The Participatory Technique, considering expert opinions and the Hierarchical Analytical Process, is satisfactory for the definition of the criteria (factors and restrictions) and their weights, that is considered a MCE differential because data on natural systems are hardly complete and fully understood. Another advantage of the Participatory Technique is allowing the solution of a conflict.

2) Both WLC and OWA enabled the identification of priority areas for protection. However, OWA offers more versatile solutions, because it considers the risktaking of the process and trade-off among criteria. This way, OWA provides a greater number of possible answers to the interest question. WLC tends to provide more general and less flexible solutions that, if not well evaluated, can conduct to uncertainties in landscape planning.

3)The correct use of these methodologies depends on a good understanding of the available techniques and the context of the landscape under study

\section{REFERENCES}

Aires URV, Santos BSM, Coelho CD, Silva DD, Calijuri ML. Changes in land use and land cover as a result of the failure of a mining tailings dam in Mariana, MG, Brazil. Land Use Policy. 2018;70:63-70. 
Babalola M. Application of GIS-Based MultiCriteria Decision Technique in Exploration of Suitable Site Options for Anaerobic Digestion of Food and Biodegradable Waste in Oita City, Japan. Environments. 2018;5(7):77.

Bax V, Francesconi W, Quintero M. Spatial modeling of deforestation processes in the Central Peruvian Amazon. Journal for Nature Conservation. 2016;29:79-88.

Bender DJ, Contreras TA, Fahrig L . Habitat loss and population decline: a meta-analysis of the patch size effect. Ecology.1998;79(2):517-533.

Blachowski J. Methodology for assessment of the accessibility of a brown coal deposit with analytical hierarchy process and weighted linear combination. J Environ Earth Sci. 2015; 74(5):4119-4131.

Bueno C, Almeida PJAL. Sazonalidade de atropelamentos e os padrões de movimentos em mamíferos na BR-040 (Rio de Janeiro-Juiz de Fora). Revista Brasileira de Zoociências. 2010;12(3):219226.

Cambui ECB,Vasconcelos RN, Mariano-Neto E, Viana BF, Cardoso MZ. Positive forestry: the effect of rubber tree plantations on fruit feeding butterfly assemblages in the Brazilian Atlantic forest. Forest Ecology and Management. 2017;397:150-156.

Castro LMA. Proposição de metodologia para a avaliação dos efeitos da urbanização nos corpos de água. Tese (Doutorado em Saneamento, Meio Ambiente e Recursos Hídrico) Universidade Federal de Minas Gerais, Minas Gerais; 2007. 297 f.

Ceia-Hasse A, Navarro LM, Borda-de-Água L, Pereira HM. Population persistence in landscapes fragmented by roads: disentangling isolation, mortality, and the effect of dispersal. Ecological Modelling. 2018;375:45-53.

CEPAGRI, 2013. Clima dos Municípios

Paulistas - Piedade. Disponível em:

$<$ http://www.cpa.unicamp.br/outras-informacoes/

clima muni 428.html>. Acesso em: 01 de out. 2013.

Chen W, Xie Z, Zhou Y. Proximity to roads reduces acorn dispersal effectiveness by rodents: Implication for forest regeneration and management. Forest Ecology and Management. 2019;433:625-632.
Comino E, Bottero M, Pomarico S, Rosso M. Exploring the environmental value of ecosystem services for a river basin through a spatial multicriteria analysis. Land Use Policy. 2014;36:381395.

Comino E, Bottero M, Pomarico S, Rosso M. The combined use of Spatial Multicriteria Evaluation and stakeholders analysis for supporting the ecological planning of a river basin. Land Use Policy. 2016;58:183-195.

Costa E, Paiva A, Seixas J, Costa G, Baptista P, Gallachóir BO. Spatial Planning of Electric Vehicle Infrastructure for Belo Horizonte, Brazil. Journal of Advanced Transportation, 2018.

Danesh G, Monavari SM, Omrani GA, Karbasi A. Compilation of a model for hazardous waste disposal site selection using GIS-based multi-purpose decision-making models. Environmental Monitoring and Assessment. 2019:122-191.

Doorga JRS, Rughooputh SDDV, Boojhawon R. Multi-criteria GIS-based modelling technique for identifying potential solar farm sites: A case study in Mauritius. Renewable Energy. 2019;133:1201-1219.

Drobne S, Lisec A. Multi-attribute decision analysis in GIS: weighted linear combination and ordered weighted averaging. Informatica, Ljubljana. 2009;33(4):459-474

Fahrig L. Effects of habitat fragmentation on biodiversity. Annual review of ecology, evolution, and systematics, Palo Alto.2003;34:487-515.

Ferretti V, Pomarico S. Ecological land suitability analysis through spatial indicators: an application of the Analytic Network Process technique and Ordered Weighted Average approach. Ecological Indicators. 2013;34:507-519.

Freitas SR, Hawbaker TJ, Metzger JP. Effects of roads, topography, and land use on forest cover dynamics in the Brazilian Atlantic Forest. Forest Ecology and Management. 2010;259(3):410-417.

Fundação Florestal do Estado de São Paulo. Resumo executivo do Plano de manejo do Parque Estadual do Jurupará. 2010. Disponível em: <http://www. ambiente.sp.gov.br/fundacaoflorestal/planos-demanejo/planos-de-manejo-planos-concluidos/>. 
Acesso em: 14 nov. 2012.

Gasparoto EAG et al. Geração de planos de informação como subsidio a avaliação multicriterial, em ambiente SIG, em Piedade. In: Jornada Científica e Tecnológica da UFSCAR 9. 2011, São Carlos. Anais... [S.1.: s.n.], 2011.

Geneletti D. Biodiversity impact assessment of roads: an approach based on ecosystem rarity. Environmental Impact Assessment Review. 2003;23(3):343-365.

Geneletti D. Formalising expert opinion through multi-attribute value functions: an application in landscape ecology. Journal of Environmental Management. 2005;76(3):255-262.

Ghadirian O, Moradi H, Madadi H, Lotfi A, Senn J. Identifying noise disturbance by roads on wildlife: a case study in central Iran. SN Applied Sciences. 2019;1(8)808.

Glista DJ, DeVault TL, DeWoody JA. A review of mitigation measures for reducing wildlife mortality on roadways. Landscape and Urban Planning. 2009;91(1):1-7.

Guzmán A, Link A, Castillo JA, Botero JE. Agroecosystems and primate conservation: shade coffee as potential habitat for the conservation of Andean night monkeys in the northern Andes. Agriculture, Ecosystems and Environment. 2016;215:57-67.

Haider S, Kueffer C, Bruelheide H, Seipel T, Alexander JM, Rew, LJ, et al.. Mountain roads and non-native species modify elevational patterns of plant diversity. Global Ecology and Biogeography. 2018;27(6):667-678.

Hamad R, Kolo K, Balzter H. Post-War Land Cover Changes and Fragmentation in Halgurd Sakran National Park (HSNP), Kurdistan Region of Iraq. Land. 2018;7(1):38.

Hernández A, Miranda M, Arellano EC, Saura S, Ovalle C. Landscape dynamics and their effect on the functional connectivityof a Mediterranean landscape in Chile. Ecological Indicators. 2015;48(1)198-206.

Instituto Brasileiro de Geografia e Estatística - IBGE. Piedade. 2017. Disponível em: https://cidades.ibge. gov.br/v4/brasil/sp/piedade/panorama. Acesso em: 13 de set. 2017.

Jeong JS, Ramírez-Gómez Á. Renewable energy management to identify suitable biomass facility location with GIS-based assessment for sustainable environment. Energy Procedia. 2017;136:139-144.

Jiang H, Eastman R. Application of fuzzy measures in multi-criteria evaluation in GIS. International Journal of Geographical Information Science. 2000;14(2):173-184.

Kamwi JM, Cho MA, Kaetsch C, Manda SO, Graz FP, Chirwa PW. Assessing the Spatial Drivers of Land Use and Land Cover Change in the Protected and Communal Areas of the Zambezi Region, Namibia. Land. 2018;7(4):131.

Kiavarz M, Jelokhani-Niaraki M. Geothermal prospectivity mapping using GIS-based Ordered Weighted Averaging approach: a case study in Japan's Akita and Iwate provinces. Geothermics. 2017;70:295-304.

Krishnadas M, Agarwala M, Sridhara S, Eastwood E. Parks protect forest cover in a tropical biodiversity hotspot, but high human population densities can limit success. Biological Conservation. 2018;223:147-155.

Lang S, Blaschke T. Análise da paisagem com SIG. Tradução de Hermann Kux. São Paulo: Oficina de Textos, 2009.

Lorentz JF, Calijuri ML, Marques EG. Multicriteria analysis applied to landslide susceptibility mapping. Nat Hazards. 2016;83(1):41-52.

Malczewski J. GIS-based land-use suitability analysis: a critical overview. Progress in Planning. 2004;62(1):3-65.

Malczewski J, Rinner C. Multicriteria Decision Analysis in Geographic Information Science. Berlin, Heidelberg: Springer, 2015.

Matsumoto M, Kumler M, Baumgarten L. Legal Geo: um aplicativo para a identificação das áreas potenciais para recuperação e implementação de Reservas Legais no Cerrado. In: Paese A, Uezu A, Lorini ML, Cunha A. (Org.). Conservação da biodiversidade com SIG. 1. ed. São Paulo: Oficina de Textos, 2012. v. 1. 240p.

Revista Árvore 2019;43(3):e430307 
Maués MM, Oliveira PEAM. Consequências da fragmentação do habitat na ecologia reprodutiva de espécies arbóreas em florestas tropicais, com ênfase na Amazônia. Oecologia Australis. 2010;14(1):238250 .

Mazerolle MJ, Villard M-A. Patch characteristics and landscape context as predictors of species presence and abundance: a review. Ecoscience. 1999;6(1):117124.

McGregor RL, Bender DJ, Fahrig L. Do small mammals avoid roads because of the traffic? Journal of Applied Ecology. 2008;45(1)117-123.

Medvecká J, Zaliberová M, Májeková J, Senko D. Role of infrastructure and other environmental factors affecting the distribution of alien plants in the Tatra Mts. Folia Geobotanica. 2018;53(3):349-364.

Metzger JP. Como lidar com regras pouco óbvias para conservação da biodiversidade em paisagens fragmentadas. Natureza \& Conservação, Curitiba 2006;4(2):11-23

Metzger JP. Uso de Índices da Paisagem para a Definição de Ações. In: São Paulo (Estado). Secretaria do Meio Ambiente. Diretrizes para a conservação e restauração da biodiversidade no estado de São Paulo. São Paulo: Instituto de Botânica; FAPESP; Programa Biota FAPESP, 2008. p. 122-129.

Mokarram M, Hojati M. Using ordered weight averaging (OWA) aggregation for multi-criteria soil fertility evaluation by GIS (case study: southeast Iran). Computers and Electronics in Agriculture. 2017;132:1-13.

Palomino D, Carrascal LM. Threshold distances to nearby cities and roads influence the bird community of a mosaic landscape. Biological Conservation. 2007;140(1):100-109.

Parendes LA, Jones JA. Role of light availability and dispersal in exotic plant invasion along roads and streams in the H.J. Andrews, Experimental Forest. Oregon. Conservation Biology. 2000;14(1):64-75.

Prefeitura de Piedade. 2012. Piedade (Município). Disponível em: $<$ http://piedade.sp.gov.br/capa. asp?IDPagina=596>. Acesso em: 05 jan. 2012.
Primack RB, Rodrigues E. Biologia da conservação. Londrina: Edição dos Editores, 2001.

Rodrigues RR, Paese A, Diederichsen ATB, Costa S, Brancalion PHS, Santiami E et al. A restauração da Mata Atlântica apoiada em sistemas de Informações Geográficas. In: Paese A, Uezu A, Lorini ML, Cunha A. (Org.). Conservação da biodiversidade com SIG. 1. ed. São Paulo: Ofícina de Textos, 2012. v. 1. 240 p.

Rodrigues E. Edge effect on the regeneration of forest fragments in Londrina. [Tese - PhD em Biologia]. Cambridge: Harvard University; 1998. $172 \mathrm{f}$.

Rodríguez-Rodríguez D, Martínez-Vega J. Landscape and Urban Planning Analysing subtle threats to conservation : A nineteen year assessment of fragmentation and isolation of Spanish protected areas. Landscape and Urban Planning. 2019;185:107-116

Saaty TL. A scaling method for priorities in hierarchical structures. Journal of Mathematics Psychology. 1977;15(3):234-281.

Schonewald-Cox C, Buechner M. Park protection and public roads. In: Fiedler PL, Jain SK. (eds.). Conservation Biology: the theory and practice of nature conservation, preservation andmanagement. London: Chapman and Hall; 1992. p. 375-395.

Silva RJ, Vieira LCG, Pinto MP, Oliveira G, Barreto BS. Malha rodoviária e conflitos de conservação no cerrado: um estudo para a preservação de anfíbios. Acta Scientiarum Biological Sciences. 2006;28(4):373-378

Silveira HLF, Vettorazzi CA, Valente ROA. Avaliação multicriterial no mapeamento de risco de incêndios florestais, em ambiente SIG, na bacia do Rio Corumbataí, SP. Revista Árvore. 2008;32(2):259-268.

Sousa COM, Freitas SR, Dias AA, Godoy ABP, Metzger JP. O papel das estradas na conservação da vegetação nativa no Estado de São Paulo. In: Simpósio Brasileiro de Sensoriamento Remoto, 14. (SBSR), 2009, Natal. Anais... São José dos Campos: INPE, 2009. p. 3087-3094. DVD, On-line. ISBN 978-85-17-00044-7. 
Suuronen A, Lensu A, Kuitunen M, Andrade-Alvear $\mathrm{R}$, Celis NG, Miranda M, et al. Optimization of photovoltaic solar power plant locations in northern Chile. Environ Earth Sci. 2017;76:824-837.

Svensson J,Andersson J, Sandström P, Mikusiński G, Jonsson BG. Landscape trajectory of natural boreal forest loss as an impediment to green infrastructure. Conservation Biology. 2019;33(1):152-163.

Tabarelli M, Gascon C. Lições da pesquisa sobre fragmentação aperfeiçoando políticas e diretrizes de manejo para a conservação da biodiversidade. Megadiversidade. 2005;1(1):181-188.

Turner MG, Gardner RH (eds.). Quantitative methods in landscape ecology: the analysis and interpretation of landscape heterogeneity. New York: Springer Verlag, 1990. v.82.

Valente ROA, Vettorazzi CA. Definition of priority areas for forest conservation through the Ordered Weighted Averaging Method. Forest Ecology and Management. 2008;256(6):1408-1417.

Valente ROA, Vettorazzi CA. Avaliação multicriterial na definição de áreas prioritárias à restauração florestal, visando o manejo sustentável da água. In: Brun AL, et al (Ed.). Sustentabilidade do uso da água nos trópicos e subtrópicos: estudos de casos brasileiros. Ijuí: Editora Unijuí, 2013. p. 285-318.

Valente ROA, Petean FCS, Vettorazzi CA. Multicriterial decision analysis for prioritizing areas for forest restoration. CERNE. 2017;23(1):53-60.

Viana VM, Pinheiro LAFV. Conservação da biodiversidade em fragmentos florestais. Série Técnica IPEF, Piracicaba. 1998;12(32):25-42.

Voogd H. Multicriteria evaluation for urban and regional planning. London: Pio; 1983.
Wang Z, Du X. Monitoring Natural World Heritage Sites: optimization of the monitoring system in Bogda with GIS-based multi-criteria decision analysis. Environ. Monit. Assess. 2016;188(7):384400.

Xiao Y, Yi S, Tang Z. Integrated flood hazard assessment based on spatial ordered weighted averaging method considering spatial heterogeneity of risk preference. Science of the Total Environment. 2017;599-600:1034-1046.

Yager RR. On ordered weighted averaging aggregation operators in multicriteria decisionmaking. IEEE Transactions on Systems, Man, \& Cybernetics. 1988;18(1): 183-190.

Zabihi H, Alizadeh M, Langat P, Karami M, Shahabi H, Ahmad A, et al. GIS Multi-Criteria Analysis by Ordered Weighted Averaging (OWA): toward an integrated citrus management strategy. Sustainability. 2019;11(4):1009.

Zhang L, Fu B, Lü Y, Zeng Y. Balancing multiple ecosystem services in conservation priority setting. Landscape Ecol. 2015;30(3):535-546.

Zhang X, Wang Z, Lin AJ. GIS Based Measurement and Regulatory Zoning of Urban Ecological Vulnerability. Sustainability. 2015;7(8):9924-9942.

Zimbres B, Machado RB, Peres CA. Anthropogenic drivers of headwater and riparian forest loss and degradation in a highly fragmented southern Amazonian landscape. Land Use Policy. 2018;72:354-363.

Zoghi M, Ehsani AH, Sadat M, Amiri MJ, karimi S. Optimization solar site selection by fuzzy logic model and weighted linear combination method in arid and semi-arid region: a case study IsfahanIran. Renewable and Sustainable Energy Reviews. 2017:68(Part. 2):986-996.

\section{ERRATA}

No artigo “MULTICRITERIAL EVALUATION IN THE DEFINITION OF PROTECTED AREAS AT THE
PIEDADE MUNICIPALITY, SP.", publicado no número 3, volume 43, da Revista Árvore, onde se lê:

Simone Sayuri Sumida ${ }^{2 *}$ and Roberta de Oliveira Averna Valente ${ }^{3}$

L eia-s e:

Simone Sayuri Sumida ${ }^{2 *}$ and Roberta Averna Valente ${ }^{3}$

Revista Árvore 2019;43(3):e430307 